\title{
The Court Jesters (Dvorní šašci)
}

\author{
Author: Viktor Fischl/Avigdor Dagan
}

First Published: 1982

Translations: Hebrew (Letsane he-hatser, 1982); English (The Court Jesters, 1989); German (Die Hofnarren, 1990); Dutch (De hofnaren, 1992); Swedish (Hovnarrarna, 1996); Romanian (Bufonii curţii, 1997); Japanese (Kyutei no dokeshi tachi, 2001); French (Les Bouffons du roi, 2006).

About the Author: Viktor Fischl (1912-2006) was a Czech poet, novelist and Israeli diplomat. He came from a Czech-Jewish family in Eastern Bohemia. Fischl began his literary career with Zionist-oriented journalism and collections of poetry. He graduated with a degree in law (1938) from Charles University, after the beginning of the Nazi occupation in 1939 he escaped to Great Britain where he worked in exile Czechoslovak Foreign Ministry. In London, Fischl was in touch with the Polish-Jewish poet Antoni Słonimski ( $\rightarrow$ Elegy for the Little Jewish Towns) whose poem Alarm he translated into Czech. In 1949 he moved to Israel and took the name Avigdor Dagan. Fischl served as an Israeli diplomat, he was an ambassador in Poland, Yugoslavia, Norway and Austria. After his retirement (1977) he returned to writing and published a large number of short stories, novels, essays and poems. He edited three volumes of Jews in Czechoslovakia: Historical Studies and Surveys released in the U. S. (1968, 1971 and 1984). Fischl's works were able to be published in Czechoslovakia again only after 1989. His translation of six books of the Old Testament from Hebrew into Czech was issued in 2002. He was also the Encyclopaedia Judaica co-editor for Czechoslovak literature.

Viktor Fischl's brother Pavel Fischl (1922-2008) was also a poet, dramatist and novelist. He survived the Holocaust in Nazi camps, worked as an actor and psychologist in Israel and the U. S. Pavel Fischl took the name Gabriel Dagan. The Fischl brothers wrote the novel The Watchmaker from Zodiac Lane (in Hebrew 1984, in Czech 1992) together.

Further Important Publications: Hebrejské melodie (1936, Hebrew Melodies; poems); Píseň o lítosti (A Song about Regret, in the Hebrew translation, 1951; in Czech 1982; novella); Moscow and Jerusalem (1970; political essay); Jeruzalémské povídky (Jerusalem Stories, in Hebrew 1982, in Czech 1985; short stories); Ulice zvaná Mamila (The Street Called Mamila, in Hebrew 1984, in Czech 2006; novel); Loučení s Jeruzalémem (Farewell to Jerusalem, 1997; novel).

\section{Content and Interpretation}

The narrator of the short novel, divided into 23 chapters, is the judge Kahana who comes from a German-Jewish intellectual family. After his birth, his nanny dropped

¿ Open Access. (c) 2021 Jiří Holý, published by De Gruyter. (cc) By-NC-ND

This work is licensed under a Creative Commons Attribution-NonCommercial-NoDerivatives 4.0 License.

https://doi.org/10.1515/9783110671056-020 
him on the floor and therefore he is hunchbacked. Nevertheless, on the other hand, he can predict the future. In the first nine chapters, Kahana describes his life in an extermination camp during World War II. He and his three friends, the dwarf Leo Riesenberg (an ironic name, Riese means giant in German), the juggler Adam Wahn (Wahn = delusion) and the astronomer Max Himmelfarb, (= sky colour) all of them Jews, are "the court jesters" of the Nazi camp commandant Major Kohl. They serve as entertainers amusing the Major and his guests. All survive the war but they are traumatised by their experience. Unfortunately, Leo is crushed by a train at the moment of returning home from the camp. Adam has to witness the murder of his wife and sets out to search for her killer, Nazi Captain Walz. Upon returning home Max finds out that his brother has been battered to death by the Nazis and his love Hilde as well as her father have been shot because of helping the Jews. As Kahana starts losing his ability to predict the future, he is convinced he can no longer be a judge.

The second half of the novel depicts life 20 years later. All three remaining friends, Kahana, Max and Adam, meet again in Jerusalem. It is just before the Six-Day Arab-Israeli War in 1967. However, Adam is badly injured by an Arab terrorist attack. Kahana and Max visit him in the hospital and Adam tells them about how he chased after Nazi Captain Walz (from Chapter 15 to Chapter 21 in flashbacks). After about a dozen years, Adam found Walz in Argentina. Adam wanted revenge but he was not able to kill him. Walz drowns himself in the sea and Adam sees his suicide as God's justice. After a few days, Adam succumbs to his injuries and dies in the Jerusalem hospital. The novel ends with Kahana's reflections about Jerusalem and God. Despite all the suffering, he

believes that people are not puppets or court jesters in the hands of God. People have to search for truth even if they sometimes do not find it.

\section{Main Topics and Problems}

The first sketch of the novel was published as a short story The Judge in Fischl's collection Jerusalem Stories. Already here the story about "four jesters" in the extermination camp is presented. Unlike to the later novel, after the war Adam Wahn is transported to a mental hospital and Max Himmerfarb commits suicide. Only the hunchbacked former judge survives and tells his doctor in Jerusalem his life events.

The novel The Court Jesters is the first part of the triptych located at Jaffa Street and surroundings in Jerusalem. The second part is The Street Called Mamila and the third Farewell to Jerusalem. In the centre of the narrative is the main character, the former judge Kahana. He has survived the Holocaust and questions the omnipotence and goodness of God in the world after Auschwitz. See Weiss' $\rightarrow$ And God Saw That It Was Bad, Kraus's $\rightarrow$ The Land without God or Knieža's $\rightarrow$ Sixth Battalion, On Guard! After Adam Wahn's death, his friend Max Himmelfarb queries:

"God? Why does cause God all this horribleness that happens? [...] Hilde, the poor small Leo Riesenberg, Wahn's wife and now Wahn herself? Why? I ask you why?” (Fischl, 1990, p. 143) 
Max doesn't find the sense of life and accuses God of bringing pain and suffering. On the other hand, Kahana's other friend in Jerusalem, Menachem Salz, an Orthodox Jew and a simple man, encourages him by saying it is necessary not to lose faith and hope.

Viktor Fischl presents the Holocaust as a breach in the civilisation. This event was disastrous, moreover, it can be repeated and varied. The terrorist attacks in the Israel and Arab-Israeli wars are reminiscent of World War II and the Shoah. Nevertheless all these tragic occurrences can be healed and overcome.

In the second novel of the Jerusalem Triptych, The Street Called Mamila, Kahana is reading the Hebrew Bible and the wind blows the Bible open to the Book of Job where he finds the idea about inability to recognise God's purpose. Human beings should turn away from evil and stick to God's wisdom (Fischl, 2006, p. 141).

Jerusalem plays an important role in Fischl's The Court Jesters as well as in the whole triptych. It is a magical place of tradition and God's presence that helps characters to find inner peace and serenity.

\section{Cited Works}

Fischl, V. (1990). Dvorní šašci. Praha: Art - Servis. Fischl, V. (2006). Ulice zvaná Mamila. Praha: Garamond.

\section{Further References}

Drbalová, J. (2009). Židovské postavy v prózách Viktora Fischla. Master Degree Thesis. Brno: Pedagogická fakulta MU. Available at: https://is.muni.cz/th/snibz/diplomova_prace1.pdf [Accessed: 04.09.2020] -el- (= Sedláková, J.). (1998). Fischl, Viktor. In: Mikulášek, A. et al. Literatura s hvězdou Davidovou. Praha: Votobia, pp. 82-85. Halamová, M. (2010). Př́běh vyprávění Viktora Fischla. Praha: ARSCI, pp. 101-132. jk (= Kudrnáč, J.). (1994). Viktor Fischl: Dvorní šašci. In: Dokoupil, B., Zelinský, M., eds., Slovník české prózy. Ostrava: Sfinx, pp. 72-74. Pojar, M. (2007). Dagan, Avigdor. In: F. Skolnik, ed., Encyclopaedia Judaica. 2nd ed., vol. 5. Detroit: Thomson Gale, pp. 377-378. Available at: https://ketab3.files.wordpress.com/2014/11/encyclopaedia-judaica-v-05-coh-doz.pdf [Accessed: 06.02.2020]. 